\title{
Beyond realism and non-realism: \\ Religious language-games and reality
}

NGTT DEEL 55, NO 1, 2014

\section{Kroesbergen, Hermen}

Postdoctoral Fellow Theology at University of Pretoria

Lecturer at Justo Mwale Theological University College (Lusaka, Zambia)

\begin{abstract}
This article attempts to take up Wittgenstein's challenge "Not empiricism and yet realism" (1991:vi 23). Language deals with reality. But we are also aware of the importance of the context with its own rules for the use of language. In trying to do justice to both sides, theology and philosophy of religion have been going back and forth between realism and non-realism. Two recent appraisals of the Wittgensteinian approach in philosophy of religion by Labron and Burley suggest that there is a way to avoid this dynamic. After analysing Labron and Burley's suggestions and their own failures to live up to the task they set themselves, this article presents an interpretation of D.Z. Phillips's concept of 'ordinary realism' to help us to stay clear from the deadlock between realism and non-realism. Our different perspectives should be regarded as viewpoints within the same reality. Taken up in our many different and diverse language-games are our primitive dealings with reality.
\end{abstract}


The way we talk about God depends upon where we were born, the people we have met, and other circumstances. Someone may come to embrace the Christian faith as an adult free agent and he may have made it truly his own through a deliberate and independent act. However, if he is born in Lusaka or Pretoria, we cannot escape the suspicion that it all would have been very different had he been born in Riyadh or Beijing. This post-modern awareness of the importance of the context with its particular language and rules has haunted philosophy of religion and theology in the twentieth century. The awareness of the relativity of our beliefs led to what came to be known as the linguistic turn, and to approaches such as non-realism: what we regard as true or false depends upon the rules that we quite arbitrarily adhere to.

After the linguistic turn, however, in the twenty-first century there seems to be a turn towards realism. This trend is visible in the 'ontological turn' in anthropology, and in the movement of 'new sincerity' in arts, but also in philosophy or religion

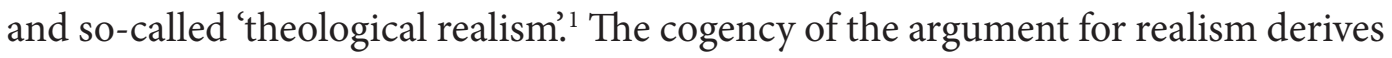
to a large extent from the desire to avoid the problems of non-realism, such as the incapability provide answers to challenges in our current globalized society. To avoid the relativism of post-modernity, philosophers and theologians alike turn towards realism. However understandable the desire to avoid relativism may be, this seems to gloss over and outright ignore the awareness of the relativity of our beliefs. People born in Lusaka generally look differently at the world from those born in Riyadh. Now, is realism the only alternative to non-realism?

In recent years two books exploring the Wittgensteinian approach in the philosophy of religion appeared, which suggest otherwise: Wittgenstein and Theology by the Canadian philosopher Tim Labron (2009) and Contemplating Religious Forms of Life. Wittgenstein and D.Z. Phillips by the British philosopher Mikel Burley (2012). Both Labron and Burley use Wittgenstein's metaphor of the fly-bottle. ${ }^{2}$ Philosophers often are like flies in a fly-bottle: their questions lead to other questions and to yet other questions, and once they are stuck with these they cannot find their way out of the myriad of questions that confront them. Regarding the debate mentioned above, it does not help to simply return to realism after the demise of non-realism. We should acknowledge both that our language is relative to the context in which we find ourselves, and that our language deals with reality. Wittgenstein emphasized that, rather than going back and forth between realism and non-realism, the only

1 See for the 'ontological turn' in anthropology Pedersen (2012); for 'new sincerity' in arts Cohn \& Russell (2012); for realism in philosophy Alston (2002); and for 'theological realism' Moore \& Scott (2007).

2 See Labron (2009:42) \& Burley (2012:3), referring to Wittgenstein (1958:309). 
way out is to trace the way back, step by step. Wittgenstein (1991:vi 23) challenges us, saying: "Not empiricism and yet realism in philosophy, that is the hardest thing." But how did so many philosophers of religion get trapped in the fly-bottle of realism and non-realism in the first place? The beginning of an answer we find in how Labron traces the history of our problem.

\section{CHALCEDONIAN REALISM?}

The temptation of realism originates according to Labron (2009:24-30) with the philosophical meditations of René Descartes. Descartes (1985:114-115, quoted by Labron 2009:24) noticed that in philosophy after all those centuries "there is still no point in it which is not disputed and hence doubtful." So, how can we ever be sure about a connection between our ideas and the external world? How can we be sure that our language is about reality? However, by phrasing the difficulty thus, already the important decisions have been made: "the problematic Cartesian separation between our ideas and the physical world" as Labron (2009:33) phrases it. It is assumed that language has meaning apart from the world, and that one can compare language and the world as two separate entities.

John Locke (1985:104, quoted by Labron 2009:31) continues in the line of Descartes and argues that the world through empirical experiences makes impressions on our empty mind, which are subsequently expressed in language, stating: "There is nothing in the intellect that wasn't previously in the senses." Our language is a representation of the world. This is philosophical realism. George Berkeley uses the same Cartesian framework the other way around and argues that our mind creates the world, that what we call 'the world' is in fact a projection of our mind and language. Labron (2009:41) summarizes: "Berkeley reduces matter to ideas since the so-called physical object is actually an idea." This is philosophical idealism or nonrealism. However, both approaches, realism and non-realism, share the Cartesian assumption that we need to find a link between the separate entities of language and reality.

Labron (2009:33-39) continues to describe how Ludwig Wittgenstein in his early philosophy was attracted to realism and wondered how our language mirrors reality. Later on he realized that in doing so he turned language into an empty shell. He realized that language does not have any meaning apart from the lives of people, however tempting it may be to investigate the connection between language and reality apart from those messy, concrete lives.

Having followed this philosophical trace, Labron (2009:65-79) draws an interesting parallel to discussions within theology. Here the tempting question is not how to connect language to reality, but how to connect our human imagination to the 
divine reality. Some theologians - Nestorians - opted for a solution similar to realism: God impresses himself on our empty imagination; others -Eutychians went the other way arguing that all we assume to know about God in the end is just projection. At the Council of Chalcedon both Nestorians and Eutychians were declared to be heretic. ${ }^{3}$ They had attempted to answer the wrong question. They should not have separated God and man in the first place. God and man are neither separable nor mixed, as is stated in the famous Christological dogma of Chalcedon. And, according to Labron (2009:68\&115), "Wittgenstein's philosophy is analogical [...] to Chalcedonian Christology," both object to the quest for connections between respectively ideas and the external world, and the human and the divine. Labron (2009:95) summarizes: "the language-games mediate our contact with reality as Christ mediates our contact with God." However, in religion a dogma may simply be announced, but in philosophical or theological reflection the work still needs to be done.

Labron attacks the frame of realism versus non-realism, but, in fact, by doing so he only reaffirms its hold. As George Lakoff (2004:3-5) famously showed in his Don't Think of an Elephant! once you get your opponent to attack your position in your terms, you have already won. By writing a book urging us to resist the debate between realism and non-realism - however noble this cause indeed is - Labron in fact makes it harder to resist it: even when you state that the concepts are confused, you confirm that they have meaning. Labron leaves us with the puzzle how to resist the entire frame of realism versus non-realism. Labron fails to provide an answer, and there are even indications that he himself - despite his own warnings - is separating language and reality.

When Labron (2009:63) hints at how he would account for the ordinary realism of the Wittgensteinian approach in the philosophy of religion, he states that: "the language-game of Christianity is tied directly to the language-games of death, birth, marriage, sin, etc." This statement is problematic in two important ways: first, there is not one language-game of Christianity, but there are many different languagegames, which could be called 'Christian'. Wittgenstein did not intend that 'languagegame' would become a technical term - in fact, part of his reason to introduce it was to cut through our technical philosophical jargon. It is clear though that he did not intend it to be used for an entity as big and complex as Christianity. To talk about language-games makes sense when we can assume that they refer to limited, specific and to some extend separate uses of language with their own distinctive rules. So we should not talk about 'the Christian language-game' or 'the religious language-

3 See Labron (2009:76-77). 
game', but we should talk for example about the language-games of praying, vocation or reincarnation. ${ }^{4}$

Second, religious language-games do not first of all relate to the language-games of death, birth etc., but to the reality of death, birth, etc. The way Labron is phrasing it suggests that there is a realm of language-games separate from reality. Our languagegames, however, are embedded in reality; they deal with reality, not just with other language-games. By his historical analysis Labron has shown us that to avoid the philosophical fly-bottle of going back and forth between realism and non-realism we need to avoid the Cartesian separation of language and reality altogether. By relating religious language-games only to other language-games, he failed this task himself. Before we investigate whether another approach is possible, let us look at Burley's analysis of the fly-bottle of realism and non-realism in which philosophers and theologians have trapped themselves.

\section{LOGICALLY PRIOR TO REALISM?}

Burley analyses both the works of Wittgenstein himself and D.Z. Phillips who most famously applied Wittgenstein's approach to philosophy of religion. Burley (2012:4) notes that many philosophers try to fit Wittgenstein and D.Z. Phillips into the debate between realism and non-realism within the philosophy of religion. Burley (2012:91) argues against "the strategy of framing Phillips' position as an instance of non-realism." Wittgenstein and Phillips stress that we should pay attention to the actual ordinary use of language. Instead of discussing language in general, philosophers should contemplate how language plays a role in ordinary contexts.

Burley (2012:7) states: "the sorts of questions around which Wittgensteinian investigations are oriented are logically prior to any question concerning the reality or unreality of the objects of religious beliefs. What both Wittgenstein and Phillips are chiefly interested in are the meanings of these beliefs." 5 They investigate the meaning of language about God by analysing how the concept of 'God' is used in different contexts. Questions like 'Does God exist?' or 'Does a metaphysically real God exist?' are meaningless without their context in day-to-day lives in Lusaka or Riyadh or wherever you may find yourself. Therefore Wittgenstein and Phillips want "to examine how language is used within religious contexts" before they deal with the

4 This is a mistake that is often made in the literature about the Wittgensteinian approach. For example Oppy \& Trakakis (2007:118) even mix talking about "religious beliefs as forming distinctive 'language games"' and "belief as a distinctive language game" on one single page.

5 See as well Burley (2012:167-169). 
existence of God, says Burley (2012:86). Wittgenstein and Phillips refuse to answer the question whether God really exists, and are therefore labelled automatically as non-realists.

Burley rightfully defends the Wittgensteinian approach against being framed in terms of the debate between realism and non-realism. However, by Burley's repeated claim that the philosophical investigations of Wittgenstein and Phillips are logically prior, he is suggesting that after listening to Wittgenstein and Phillips, we can in a meaningful way debate whether a metaphysically real God exists. Then we would be back within the frame of realism versus non-realism again, which Burley himself has urged us to avoid.

Now, D.Z. Phillips himself often used the phrase "logically prior" as well, but in a slightly different way. Phillips (2001:294) for example stated that his inquiries were "logically prior to particular assertions of belief or non-belief." Here Phillips is talking about assertions of belief and non-belief, that is: in ordinary every-day life - which is something completely different from philosophical realism and nonrealism. Contrary to what Burley is suggesting, Phillips holds that both philosophical realism and non-realism are confused and will never make sense even after countless Wittgensteinian investigations have taken place.

Burley discusses an example of an instance where according to him Phillips himself flies into the fly-bottle of realism and non-realism. Phillips points out some logical problems concerning the concept of 'reincarnation'. Burley notes that in our ordinary world many millions of people believe in reincarnation and they must have some criteria to deal with these logical problems. ${ }^{6}$ Phillips, Burley argues, should concentrate on those practices rather than in the abstract pointing out philosophical problems with reincarnation.

However, Burley (2012:114) is making the same mistake here, that he - quite correctly - ascribes to Phillips, when he refers to "[c]ultures in which a belief in reincarnation is prevalent." It is not the case that reincarnation does not exist, but neither is it the case that those many millions of people Burley refers to, believe that reincarnation does exist. These millions of people do not hold a belief in reincarnation, they live in a world with reincarnation - and that is something different. Look for example at the Bollywood-movie Agneepath in which a son is searching for the approval by his mother for all his life. Just before his death his mother tells him: "I will ask the

6 See Burley (2012:113-115).

7 Malhotra (2012). 
Lord to be your mother again in the next life." These two people live in a world with reincarnation. ${ }^{8}$

Both Labron and Burley convincingly argue that all language is dependent upon the lives of the people speaking that language. Statements are not true or false independent of these lives, as philosophical realists presuppose. We need to avoid questions such as whether God or reincarnation exist, but investigate what people mean when they use these concepts. On the other hand, in their language people deal with an external reality, contra the ideas of non-realists. Avoiding the Cartesian separation of language and reality does not imply doing away with reality, on the contrary: in our religious language-games we are dealing with reality. How can we avoid going back and forth between realism and non-realism, recognizing both our awareness of the importance of the context with its own language and rules, and the fact that in our language we are dealing with reality? Labron and Burley point in the right direction, but fail to come up with an answer. Taking our lead from D.Z. Phillips's idea of 'ordinary realism', however, we will argue that a way out of the flybottle of realism and non-realism is possible.

\section{VIEWPOINTS IN THE SAME REALITY}

Many of his colleagues reckon that D.Z. Phillips "never quite succeeds in being a realist", as philosopher Andrew Moore (2003:91) puts it. ${ }^{9}$ On the other hand Phillips (2000b:36) explicitly denies being a non-realist: "I am not propounding any form of non-realism." He (1999:76) holds that "[t]he real need, however, is to cut through the realism/nonrealism debate. We need to appreciate that our philosophical choice is not between realism and a mere plumping for some perspective." ${ }^{10}$ And then, according to Phillips (2000b:36), "[a]fter their demise, we simply have ordinary realism." Now, can we make sense of Phillips's claim to 'ordinary realism' in philosophy of religion, and is this a viable alternative to both non-realism and realism in philosophy and theology?

I take my lead here from what Phillips (2001:322) wrote referring to an article by Winch: "I take Winch's point that moral differences, where the conceptual gap between them is great, are not perspectives on a common reality. I think it is rather

8 Although I personally would not say something like this, I think I can understand it. I can admire this statement, and I think I take mother and son serious in doing so without answering the question whether reincarnation does or does not exist in reality.

9 See for some other recent accusations that Phillips is a non-realist: Byrne (2003: 8); Oppy \& Trakakis (2007:106); and Hilberg (2009:83).

10 See as well Labron (2009:23\&52) \& Burley (2012:4\&87). 
different if one says they are viewpoints in the same reality, by which I mean that they cut across and impinge on each other in countless ways in the hubbub of voices in our own and other cultures." This interpretation of language-games differs from that of other interpreters of Wittgenstein, who regard language-games as presupposing a picture of reality - either conventional or realistic. ${ }^{11}$ Phillips holds that languagegames express viewpoints within one and the same real reality, shared by all speakers of language, religious and non-religious. Language-games are not based on particular descriptions of reality, but are viewpoints within a given reality. Taking this point of departure, which was never further elaborated by Phillips himself, I will now attempt to show how this may provide a perspective that avoids the problematic dynamic of realism and non-realism that Labron and Burley detected.

There are many different language-games; someone who is born in Lusaka learns to participate in different language-games than someone who is born in Riyadh. The language-games themselves are not true or false; rather, the rules of the languagegame determine what we call true and false. It is our human agreement that determines when something should be called true and when false. However, truth can still correspond to what we usually think of as making it correct to say 'is true' of a statement, that is: the statement corresponds to the way things are in reality. Recognizing the importance of language-games, rules and human agreement does not exclude that. To show this, let me first use actual games as example.

In soccer there are rules for when something is really a goal: the ball should be pushed over the line of the goal, not by hand, not from an offside position, etc. Humans have agreed that those are the rules. This does not mean that it is human agreement that decides whether team A or team B has scored a goal. Humans have agreed on the rules, but the ball should be across the line in reality. Whether it is or not, is something we check in the world, not something we decide upon. In the rules that humans have agreed upon it is determined which aspect of reality is relevant in this respect. When we play indoor soccer, a basketball ring may be above the playing field. Accidently the ball may go through this ring. In soccer this is irrelevant. In basketball you would look closely to see whether or not the ball really went through the ring, in a game of soccer that does not matter. Everyone may agree that the football really did go through the ring, but that is irrelevant. Human agreement made up the rules for what is truly a goal in soccer, but that does not mean that

11 See Ellenbogen (2003) who argues that Wittgenstein's conception of truth implies that what we call 'true' is based upon our human conventions and cannot transcend our current capacity for knowledge; and Brümmer (2006) who argues that language-games are constituted by tacit presuppositions about reality. 
reality is out of the picture - far from it: in the rules we have decided, agreed upon, what aspects of reality are important to consider.

Just like in ordinary games, in language-games the rules of the language-games are made up by human beings, but in these rules we refer to reality. In the rules of the language-game it is decided which part of reality is relevant to us and in what way. For someone who considers a dangerous journey, it may be important whether or not a chicken that has been administered a sacramental poison survives. ${ }^{12}$ I would be able to see whether the chicken really does or does not survive, but to me that would not be relevant. To this man who participates in the language-game of consulting an oracle, it is. For me the survival of the chicken would be just like the ball going through the basketball ring during indoor soccer: it really happened, but it does not matter.

Human agreement in our different language-games settled the rules for what in reality is important. This may be something very different from one language-game to the next, just like the rules for what is really a goal differ from soccer to basketball. This does not mean that all these language-games are isolated islands. They do bear on each other. And we may gain insights from people who play different languagegames than we do. For me it would be hard to see how the chicken's survival was relevant, but perhaps in this man's practice the hazard of our personal decisions is better accounted for than in my own. Looking at the language-games of others may enrich our understanding of the world we share.

Our language-games determine how we live within reality, what aspects of reality are important to us. This is not denying the existence of truth in the sense of 'that what is in accordance with reality'. Understanding our language-games with 'believe' would imply finding out the rules for what is important in reality within these language-games. This interpretation of language-games avoids the Cartesian separation of language and reality, without doing away with reality: in our languagegames we are dealing with reality. The language-game determines which aspect of reality is important, where we bump into reality. Now, do we bump into reality in our religious language-games as well? This seems be a slightly different case.

\section{BUMPING INTO REALITY}

What do we look for in reality when we are participating in religious languagegames? Where might we bump into reality in religion? Let us take three students who try to convince their churches of their vocation to become a minister: one tells

12 Example adapted from Evans-Pritchard (1937). 
the committee that he wanted to study law, but when he was turned down by law school again and again, he realized that God was telling him to follow this different path; the second one had been told by people that he should become a minister for many years now; and the third had always felt such a strong inner conviction that he should become a minister that he could not be swayed by anyone not to go on this path. Three very different stories, but all of these students have been contemplating 'outside' confirmation, they have bumped into reality: either by being rejected at law school, by what people were telling, or by the conviction that the third one found in his own heart. The way you bump into reality and the way you look for 'outside' confirmation may be different in religion from what it is in the empirical sciences, but this does not mean that it is not there. Being able to bump into reality is just as much part of the concept of 'reality' in religion as it is of the concept of 'reality' in many other areas.

Now imagine that you know you can say 'I am called' according to the rules of the language-game in which you participate, but you still do not know whether you should actually say that you are called. Is there somewhere in reality where you can look? In a way there is, in a way there is not. Let me illustrate this by using an example from outside religion.

Imagine someone asks you to forgive him. You consider the possibilities. You are aware that you can say you forgive him, or you can say that he has hurt you too much so at the moment you cannot forgive him. Both statements would be regarded as perfectly normal. They both fit the circumstances; they both fit your personality. Now, what do you say? Whatever you say will from then on be part of who you are. It is both a discovery about what kind of person you are, and a decision about what kind of person you want to be. I think it makes sense to say that you often feel what you must say, whether you can forgive him or not.

But this is not the end of it. Suppose you say that you forgive him, because you feel that way and you genuinely intend to forgive him. Nonetheless, later on you discover that you cannot treat him as you did before the whole affair. You don't want to, but you see him differently. In many language-games with the concept forgiveness, however, you should not do this. You have only really forgiven someone if the way you treat him is no longer related to the hurtful event. You knew this, you were aware of this part of the rules of this language-game. You thought and you felt that you could forgive him, but apparently you cannot. In the rules of the languagegame it is determined that for forgiveness to be real, you must look at the way you treat someone afterwards. You felt you could and should forgive, but later on you found out that you could not. The rules of the language-game tell you what part of reality is relevant. You knew where to look, and your initial feeling that you could 
forgive was kind of an educated guess, but the future - the future reality - showed something else.

In this example we see the important difference between knowing what could be said meaningfully in a specific situation, and knowing what you should say there and then, the difference between knowing what could be true and saying what is true to yourself, hoping and anticipating that it is the truth. ${ }^{13}$ You knew the criteria of the language-game in which you were involved. You chose what you genuinely thought was true, but later on reality showed you were wrong. You bumped into reality.

\section{RELIGIOUS LANGUAGE-GAMES AND REALITY}

Now, on this account of language-games and reality, what do our language-games show about reality? As said in the example of reincarnation above, our languagegame with reincarnation shows that reality is such that the concept of reincarnation is usable, and actually being used. Does this give us any factual knowledge about the world? No, our language games are not making factual statements about the world, but are part of our living in the world. Our language-games are not based on statements about the world. The agreement of which our language-games are an expression is not an agreement in opinions, but in form of life, as Wittgenstein (1958:241) put it. Elsewhere Wittgenstein (1972:204) states that our acting lies at the bottom of our language-games.

Taking our lead from Phillips's statement that our language-games express viewpoints in the same reality, gives a new meaning to his earlier remarks on our initial reactions to the world which he calls 'primitive reactions' - using a term borrowed from Wittgenstein. Our primitive reactions are taken up in our languagegames. For example in his article 'On Really Believing' Phillips (1993:39) states:

"Unless we agreed in our colour reactions, we would not know what it means to entertain beliefs about colours changing, fading or being renewed.

But our reactions are what we do. They are not consequences of our beliefs.

Without agreement in reactions there would be nothing to have beliefs about."

13 In Phillips's work since 1996, following Rush Rhees and Peter Winch, the difference between knowing what could be said meaningfully in a specific situation, and knowing what you should say there and then, has become important. See for example Phillips (2000a). 
This can be done in many different ways. Take the example of colours: in our language-games we distinguish between blue and black, whereas the ancient Greeks did not bother to do so. They will have reacted differently to the colour of the day sky and the night sky, but these different reactions did not result in different concepts. The other way around, we use a single concept of 'romantic love' to cover as different aspects as sexual attraction, producing offspring and being soul mates, whereas for the ancient Greeks these three were completely separate. To philosophically elucidate a language game we need to uncover which primitive reactions are taken up into it. ${ }^{14}$ As Phillips (1993:86) states: "The concepts are themselves rooted in these common reactions and responses."

Of course the way in which a philosopher describes primitive reaction, betrays the philosopher's own language-games in which these primitive reactions are taken up. As long as we are willing to acknowledge that, it does not matter, since the goal is no longer disinterested description, but understanding. Unlike in the Kantian transcendental method where a philosopher tries to infer from our current experience what the world must be like, the Wittgensteinian philosopher tries to infer which primitive reactions, which of our primitive dealings in reality are taken up in our language-games. The interest in primitive reactions is not because they would be foundational to our language-games, but because they may elucidate their sense to reach understanding. As Cora Diamond (2005:108) says about examining simpler language-games: "Wittgenstein's methodology often involves the examining of language-games simpler than ours, not because they reveal an essence, but because they can help us to avoid the moves that lead us into philosophical difficulties when we think about our own modes of thought."

The importance of investigating primitive reactions in philosophy of religion may open new ways to engage in collective enterprises together with other sciences, such as for example displayed in the Dutch primatologist and ethologist Frans de Waal's The Bonobo and the Atheist: In Search of Humanism among the Primates (2013). Where would we look in the lives of primates to see whether they display for example primitive reactions that are taken up in our language-game of vocation? As philosophers of religion we would not be as interested in the actual outcome of this research, as we are in imagining the shape such a research would take. We would not be investigating primitive reactions to find the foundations of our language-

14 As I mentioned in footnote 8 above I can understand the mother using the language-game of reincarnation in the above mentioned movie Agneepath as far as I recognize the primitive reactions that are taken up into it, in this case for example the maternal love and the need to express this on a scale beyond this life. 
games, but to contemplate and elucidate the nature of our language-games by asking ourselves what aspects in primates would interest us to see for example something taken up in our language-game of vocation. Such questions may help to find a way in which the sciences, philosophy of religion and theology together can form an epistemic community attempting to understand the one reality in which we live, despite all our different viewpoints within that reality. ${ }^{15}$ This would provide a way to avoid questions such as whether God or reincarnation exist that Burley showed to be meaningless, and to investigate what people mean when they use these concepts.

\section{CONCLUSION}

Trying to do justice to either our awareness of the importance of the context with its own language and rules, or the fact that in our language we are dealing with reality, philosophies of religion and theology have been going back and forth between realism and non-realism. Labron and Burley have suggested that the Wittgensteinian approach may provide a way out of this metaphorical fly-bottle. Avoiding their failures to live up to this challenge I presented an interpretation of D.Z. Phillips's concept of ordinary realism that can help us to stay clear from the deadlock between realism and non-realism. Our different perspectives are viewpoints in the same reality. In the way I interpreted this suggestion it allows us to acknowledge both that our language is relative to the context in which we find ourselves, and that our language deals with reality. We can elucidate these different and diverse dealings with reality by investigating our primitive reactions or primitive dealings with reality, which are taken up, into our language-games. Scott and Moore (1997:418) conclude their assessment of Phillips's work by quoting Wittgenstein (1991:vi 23) saying "Not empiricism and yet realism in philosophy, that is the hardest thing", adding that: "It is a thing that awaits adequate treatment by Wittgensteinians in the philosophy of religion." I hope to have done so in this article.

\section{BIBLIOGRAPHY}

Alston, W. P. (ed.) (2002). Realism and Antirealism. Ithaca, NY: Cornell University Press.

Brümmer, V. (2006). Brümmer on Meaning and the Christian Faith: Collected Writings of Vincent Brümmer. Aldershot: Ashgate.

15 See Buitendag (2013). 
Buitendag, J. (2013). "Gaan na die mier, kyk na sy weë en word wys: Metafoor of paradigma?". HTS Teologiese Studies/Theological Studies 69(1), Art. 1976: 1-9.

Burley, M. (2012). Contemplating Religious Forms of Life. Wittgenstein and D. Z. Phillips. New York: Continuum.

Byrne, P. (2003). God and Realism. Aldershot: Ashgate.

Cohn, R. \& Russell, J. (2012). New Sincerity. Book on Demand.

Descartes, R. (1985). The Philosophical Writings of Descartes. J. Cottingham, R. Stoothoff \& D. Mudoch (trans.). Cambridge: Cambridge University Press.

Diamond, C. (2005). "Wittgenstein on Religious Belief. The Gulfs Between Us". In D. Z. Phillips \& M. von der Ruhr (eds.), Religion and Wittgenstein's Legacy. Aldershot: Ashgate, pp. 99-138.

Ellenbogen, S. (2003). Wittgenstein's Account of Truth. Albany: State University of New York Press.

Evans-Pritchard, E. E. (1937). Witchcraft, Oracles and Magic among the Azande. Oxford: Clarendon Press.

Hilberg, N. S. (2009). Religious Truth and Religious Diversity. New York: Peter Lang.

Labron, T. (2009). Wittgenstein and Theology. London: T\&T Clark.

Lakoff, G. (2004). Don't Think of an Elephant! Know Your Values and Frame the Debate. White River Junction: Chelsea Green Publishing Company.

Locke, J. (1985). An Essay Concerning Human Understanding. P. H. Nidditch (ed.). Oxford: Claredon Press.

Malhotra, K. (dir.) (2012). Agneepath. India: Dharma Productions.

Moore, A. (2003). Realism and Christian Faith. God, Grammar, and Meaning. Cambridge: Cambridge University Press.

Moore A. \& Scott M. (1997). “Can Theological Realism Be Refuted”. Religious Studies 33, pp. 401-418. 
Moore A. \& Scott M. (2007). “Introduction”. In A. Moore \& M. Scott (eds.), Realism and Religion: Philosophical and Theological Perspectives. Aldershot: Ashgate, pp. 1-9.

Oppy, G. \& Trakakis, N. (2007). “Religious Language Games”. In A. Moore \& M. Scott (eds.), Realism and Religion: Philosophical and Theological Perspectives. Aldershot: Ashgate, pp. 103-130.

Pedersen, M. A. (2012). “Common Nonsense. A Review of Certain Recent Reviews of the 'Ontological Turn”'. Antropology of This Century 5.

Phillips, D. Z. (1993). Wittgenstein and Religion. Basingstoke: Macmillan.

Phillips, D. Z. (1999). Philosophy's Cool Place. Ithaca, NY: Cornell University Press.

Phillips, D. Z. (2000a). “Beyond Rules”. History of Human Sciences 13/2: 17-36.

Phillips, D. Z. (2000b). Recovering Religious Concepts. Closing Epistemic Divides. Basingstoke: Macmillan.

Phillips, D. Z. (2001). Religion and the Hermeneutics of Contemplation. Cambridge: Cambridge University Press.

Waal, F. de (2013). The Bonobo and the Atheist: In Search of Humanism among the Primates. New York: W. W. Norton.

Wittgenstein, L. (1958). Philosophical Investigations. Third Edition. G. E. M. Anscombe (trans.). Eaglewood Cliffs: Prentice Hall.

Wittgenstein, L. (1972). On Certainty. G. E. M. Anscombe \& G. H. von Wright (eds.). D. Paul \& G. E. M. Anscombe (trans.). New York: Harper \& Row.

Wittgenstein, L. (1991). Remarks on the Foundations of Mathematics. Revised Edition. G. H. von Wright, R. Rhees \& G. E. M. Anscombe (eds.), G. E. M. Anscombe (trans.). Cambridge, Mass.: MIT Press.

\section{KEY WORDS}

Realism

Non-realism

Language-games

Wittgenstein 
D.Z Phillips

Philosophy of religion

\section{TREFWOORDE}

Realisme

Nie-realisme

Taal-speletjies

Wittgenstein

DZ Phillips,

Filosofie van godsdiens

\section{CONTACT DETAILS}

c / o University of Pretoria, Faculty of Theology

Department Dogmatics and Christian Ethics

Private Bag x20

Hatfield, Pretoria 0028

South Africa 